\title{
THE EFFECT OF HEAT ON HYDROLYTIC ENZYMES AND SPERMATOGENESIS IN THE RAT TESTIS
}

\author{
A. W. BLAGKSHAW AND D. HAMILTON \\ Department of Physiology, University of Queensland, St Lucia 4067, Brisbane, \\ Queensland, Australia
}

(Received 8th Fanuary 1970, revised 1st April 1970)

\begin{abstract}
Summary. Immersion of the scrotal rat testis in water at $42^{\circ} \mathrm{G}$ for 30 min produces dye chromophilia within $1 \mathrm{hr}$ (eosin or alcian blue) in pachytene and diplotene primary spermatocytes. Within $2 \mathrm{hr}$, changes in acid phosphatase and amino-peptidase reactions occur. Chromatin is lost and only cytoplasmic remnants remain after $30 \mathrm{hr}$. More severe damage $\left(43^{\circ} \mathrm{C}\right.$ for $1 \mathrm{hr}$ ) increases the amounts of free acid phosphatase and proteinase in the testis.
\end{abstract}

The scrotal testis of mammals is normally at a temperature several degrees below that of the body core. A rise in testicular temperature for more than a few minutes to a level slightly above that of the core temperature leads to damage of some of the spermatogenic cells. Most investigators have examined testicular changes at intervals of $24 \mathrm{hr}$ or more after heat stress (Steinberger \& Dixon, 1959; Turpeinen, Turpeinen \& Talanti, 1962; Chowdhury \& Steinberger, 1964; Collins \& Lacy, 1969), although Waites \& Ortavant (1968) have described relatively early changes beginning at $12 \mathrm{hr}$. These studies indicated that the extent of damage was related to the temperature and duration of exposure, and that the primary spermatocytes were probably the most sensitive cells to temperature elevation.

Recent experiments in this laboratory have shown that immersion of the scrotal testis of the rat in water at $42^{\circ} \mathrm{C}$ for 30 min leads to cytological changes which are first seen $1 \mathrm{hr}$ after heating and are marked by $2 \mathrm{hr}$. The first change is a strong chromophilia of the cytoplasm of the pachytene primary spermatocytes of stages I to IV (Roosen-Runge \& Giesel, 1950) to eosin in the haematoxylin and eosin staining or alcian blue in the Feulgen-alcian blue technique (Pl. 1, Fig. 1). Over the next $24 \mathrm{hr}$, breakdown of the nuclear chromatin occurs leaving a chromophilic remnant which disappears by $30 \mathrm{hr}$.

The histochemical demonstration of acid phosphatase, with sodium $\alpha$-naphthyl phosphate as substrate and Fast Blue BB as coupling agent (Pearse, 1960) has shown changes in this enzyme which, within $2 \mathrm{hr}$ of heating, are confined also to the pachytene primary spermatocytes of stages I to IV. In control tubules, acid phosphatase is prominent in these cells as a regular pattern of granules in the cytoplasm. This is distorted in the heated tubules and in the affected cells, 
large aggregates of granules are seen, which are marked at $4 \mathrm{hr}$ but at $24 \mathrm{hr}$ are less prominent (Pl. 1, Fig. 2).

The rapid loss of DNA and the change in acid phosphatase staining, which was paralleled by a similar reaction for aminopeptidase, suggested a lysosomal effect after heating the testis.

Preliminary biochemical estimates of free and total acid phosphatase (Torriani, 1960) and acid proteinase (Barrett, 1967) in testis homogenates have shown an increase in the proportion of free enzyme after heating to $43^{\circ} \mathrm{C}$ for $1 \mathrm{hr}$ (Table 1). In this series, extensive damage occurred in a wide range of spermatogenic stages and cell types and by $24 \mathrm{hr}$, fat staining by Oil Red $\mathrm{O}$ was prominent.

\section{TABLE 1}

THE EFFECT OF HEATING THE RAT TESTIS TO $43^{\circ} \mathrm{C}$ FOR 1 HR ON THE PROPORTIONS OF FREE ACID PHOSPHATASE AND ACID PROTEINASE

\begin{tabular}{|c|c|c|c|}
\hline $\begin{array}{c}\text { Water bath } \\
\left({ }^{\circ} \mathrm{C}\right)\end{array}$ & $\begin{array}{l}\text { Hr after } \\
\text { heating }\end{array}$ & $\begin{array}{c}\begin{array}{c}\text { Acid } \\
\text { phosphatase }\end{array} \\
\quad \% \text { free }\end{array}$ & $\begin{array}{l}\text { Acid } \\
\text { proteinase } \\
\text { nzyme) }\end{array}$ \\
\hline $\begin{array}{l}33 \\
43 \\
43\end{array}$ & $\begin{array}{r}24 \\
4 \\
24\end{array}$ & $\begin{array}{l}53(5) \\
66(4) \\
61(5)\end{array}$ & $\begin{array}{r}6(5) \\
13(5) \\
20(5)\end{array}$ \\
\hline
\end{tabular}

The number of replications is given in parentheses after each percentage value.

The precipitating factor in heat damage has been suggested as hypoxia (Waites \& Setchell, 1964) or substrate deficiency (Ewing, Baird \& VanDemark, 1966), both induced as a result of an imbalance between testicular blood flow and the demands of increased testicular metabolism. Nevertheless, Steinberger \& Tjioe (1969) have shown recently that ischaemia of the rat testis for up to $1 \mathrm{hr}$ does not produce microscopically demonstrable abnormalities in the seminiferous epithelium. Longer periods of ischaemia (90 to $105 \mathrm{~min}$ ) damage spermatogonia and resting primary spermatocytes while, after $120 \mathrm{~min}$, there is a general non-specific degeneration.

The damage produced by relatively mild heat treatment of the rat testis is confined, at least in the first 24 to $30 \mathrm{hr}$, to primary spermatocytes in the later pachytene stage of prophase or at the time of reduction division. A rather more severe application of heat to the ram testis (Waites \& Ortavant, 1968) affected some type B spermatogonia which degenerated. The response of the testis to different noxious agents has been discussed by Steinberger \& Dixon (1959) and Chowdhury \& Steinberger (1964) and it is clear that the gonad behaves in a very specific fashion to different injurious agents unless the injury is excessive, when a general necrosis of the spermatogenic tissue occurs (Steinberger \& Tjioe, 1969).

The initial chromophilia and the later response of hydrolytic enzymes suggests that heat damages the cellular membranes at a critical stage of develop- 
PLATE 1

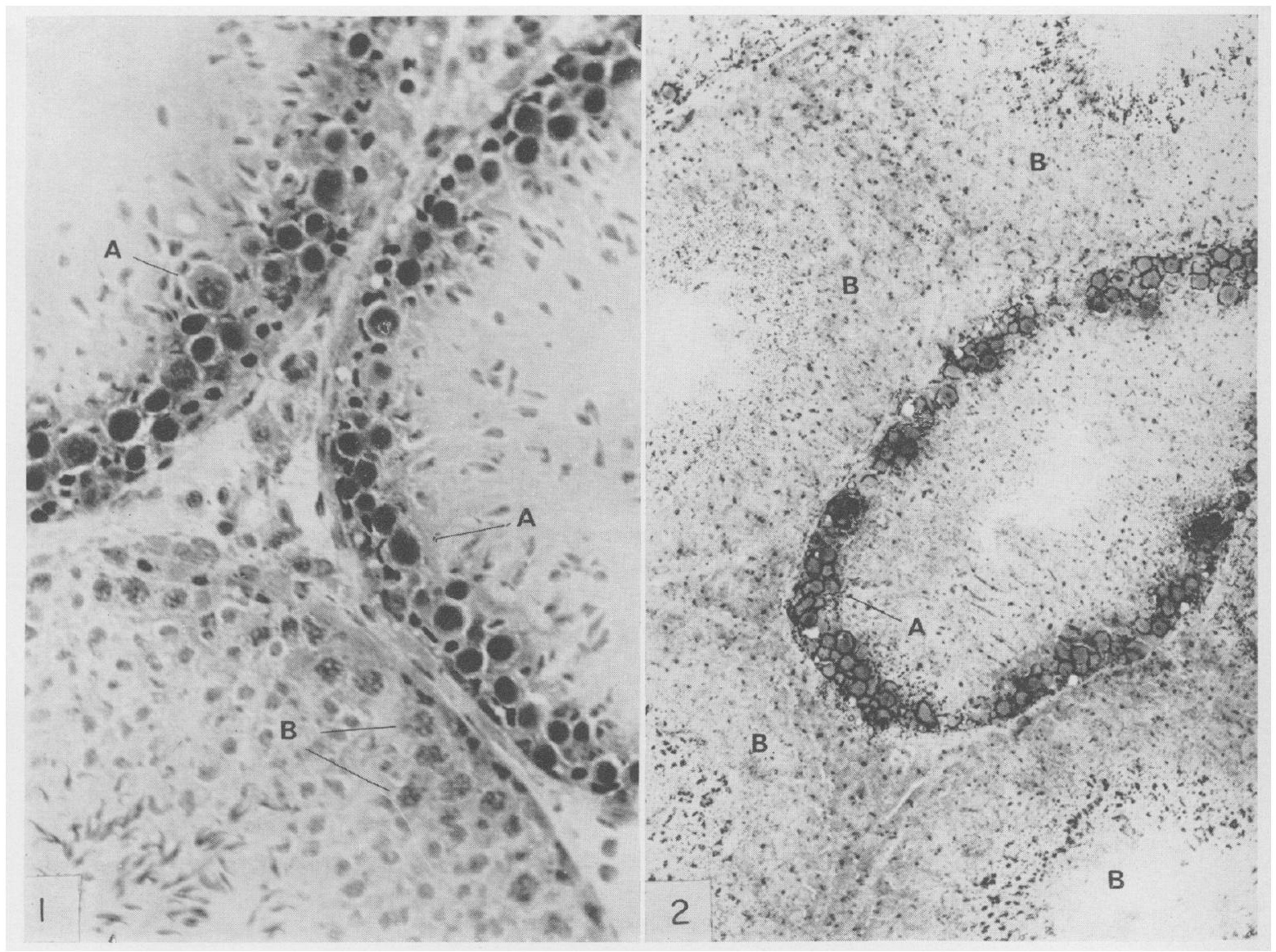

Histochemical reactions of rat testis $4 \mathrm{hr}$ after heating to $42^{\circ} \mathrm{C}$ for $30 \mathrm{~min}$.

FIG. 1. Haematoxylin and eosin staining showing eosinophilic cells (A) in stage III tubules and normal cells $(B)$ in a stage VIII tubule. $\times 320$.

FIG. 2. Acid phosphatase reaction with prominent staining in damaged cells (A) which contrasts with the reaction in normal tubules $(\mathrm{B}) . \times 150$. 
ment of the primary spermatocyte. The activation of lysosomes may be direct or may be triggered by unknown events and the lysosomal enzymes then complete the dissolution of the cell. Laufer \& Davies (1969), in their 'unitary' theory of myocarditis, propose that injury to the cell membranes leads to major ionic imbalance, mitochondrial damage and then activation of the lysosomes. As yet, evidence for alterations in testicular succinate dehydrogenase (a mitochondrial enzyme) has not been conclusive.

\section{REFERENCES}

BARretT, A. J. (1967) Lysosomal acid proteinase of rabbit liver. Biochem. 7. 104, 601.

Chowdhury, A. K. \& Steinberger, E. (1964) A quantitative study of the effect of heat on germinal epithelium of rat testes. Am. F. Anat. 115, 509 .

Collins, P. \& LACY, D. (1969) Studies on the structure and function of the mammalian testis. II. Cytological and histochemical observations on the testis of the rat after a single exposure to heat applied for different lengths of time. Proc. R. Soc. B, 172, 17.

Ewing, L. L., Baird, E. R. \& VanDemark, N. L. (1966) Comparative metabolic activity of testis and kidney cortex slices of normal and hypoglycemic chickens and rabbits. Comp. Biochem. Physiol. 17,455 .

LAUfer, A. \& Davies, A. M. (1969) Experimental granulomatous myocarditis: genesis and immunological aspects. Ann. N.Y. Acad. Sci. 156, 91.

Pearse, A. G. E. (1960) Histochemistry, theoretical and applied, 2nd edn, p. 882. Churchill, London.

Roosen-Runge, E. C. \& Giesel, L. O. (1950) Quantitative studies on spermatogenesis in the albino rat. Am. 7. Anat. 47, 1.

Steinberger, E. \& Dixon, W. J. (1959) Some observations on the effect of heat on the testicular germinal epithelium. Fert. Steril. 10, 578.

Steinberger, E. \& TJIOE, D. Y. (1969) Spermatogenesis in rat testes after experimental ischemia. Fert. Steril. 20, 639.

TORRIANI, A. (1960) Influence of inorganic phosphate on the formation of phosphatases by Escherichia coli. Biochim. biophys. Acta, 38, 460 .

Turpeinen, P., Turpeinen, O. \& Talanti, S. (1962) Effect of local heat in vivo on hyaluronidase, succinic dehydrogenase and phosphatases of the rat testis. Endocrinology, 70, 731.

Waites, G. M. H. \& Ortavant, R. (1968) Effets précoces d'une brève élévation de la température testiculaire sur la spermatogenèse du belier. Annls Biol. anim. Biochim. Biophys. 8, 323.

WAites, G. M. H. \& SETchell, B. P. (1964) Effect of local heating on blood flow and metabolism in the testis of the conscious ram. F. Reprod. Fert. 8, 339. 